\title{
Ultrastructure and Transovarial Transmission of Endosymbiotic Microorganisms in Palaeococcus fuscipennis (Burmeister) (Insecta, Hemiptera, Coccinea: Monophlebidae)*
}

\author{
Teresa SzKLARZEWICZ, Katarzyna KęDRA and Sylwia NiżNIK
}

Accepted January 25, 2006

\begin{abstract}
SZKLARZEWICZ T., KĘDRA K., NIŻNIK S. 2006. Ultrastructure and transovarial transmission of endosymbiotic microorganisms in Palaeococcus fuscipennis (Burmeister) (Insecta, Hemiptera, Coccinea: Monophlebidae). Folia biol. (Kraków) 54: 69-74.

Ovaries of Palaeococcus fuscipennis (Burmeister) are accompanied by large organs termed bacteriomes which are composed of large cells termed bacteriocytes. Each bacteriocyte is surrounded with small epithelial cells. The bacteriocyte cytoplasm is tightly packed with pleomorphic bacteria, whereas in epithelial cells small coccoid microorganisms are present. The number of coccoid bacteria is significantly lower than pleomorphic bacteria. The ovarioles containing choriogenic oocytes are invaded both by pleomorphic as well by coccoid bacteria. Microorganisms traverse the follicular epithelium and enter the perivitelline space. During advanced choriogenesis, endosymbionts are accumulated in the deep depression of the oocyte. Bacteria do not enter the ooplasm until the end of oocyte growth.
\end{abstract}

Key words: Endosymbiotic microorganisms, scale insects, transovarial transmission.

Teresa SZKLARZEWICZ, Katarzyna KĘDRA, Sylwia NIŻNIK, Department of Systematic Zoology and Zoogeography, Institute of Zoology, Jagiellonian University, R. Ingardena 6, 30-060 Kraków, Poland.

E:mail:szkla@zuk.iz.uj.edu.pl

In scale insects, like in other plant sap-sucking hemipterans, endosymbiotic microorganisms commonly occur. The presence of endosymbionts in the insect body is associated with a restricted diet, deficient in some essential amino acids (for detailed information see BUCHNER 1965; DOUGLAS 1989; ISHIKAWA 1989; BAUMANN \& MORAN 1997; MORAN \& BAUMANN 2000; BAUMANN 2005). In the body of the host insect, endosymbionts are harbored in specialized cells termed bacteriocytes (formerly mycetocytes) that are usually grouped in large organs termed bacteriomes (formerly mycetomes).

Endosymbioses (i.e. types of endosymbiotic microorganisms, their localization in the body of host insects, their transmission) in plant-sucking hemipterans have been extensively studied by BUCHNER $(1965,1966,1967,1969)$ who has shown that endosymbiotic microorganisms occur both in primitive as well as in advanced families of scale insects (for classification of scale insects see KOTEJA
1974) and are much more diverse than endosymbionts in the remaining hemipterans. According to KOTEJA $(1984,1985)$, this diversity is a consequence of: (1) permanent contact with microorganisms at the time scale insects lived in litter (i.e. before the radiation of this group of insects), (2) transition of feeding behavior from semisaprophagic before the radiation to plant-sucking after the radiation. Asymbiosis in scale insects is very rare. In primitive families (Steingeliidae, Kuwaniidae, Xylococcidae, Matsucoccidae) asymbiosis is probably of a primary nature, whereas in advanced families (Apiomorphidae, Kermesidae, Dactylopiidae) endosymbionts have been secondarily lost (BUCHNER 1965; KOTEJA 1985). It should be noted that KOTEJA and co-workers (2003) using electron microscopy revealed the occurrence of numerous gentle, rodlike bacteria in ovaries of Steingelia gorodetskia (Steingeliidae). Thus, this indicates that knowledge of the transmission of endosymbiotic microorganisms in primitive scale insects is incomplete.

*Supported by Research Grant DS/IZ/ZS/2005. 
BUCHNER (1.c.) has indicated that in scale insects, like in other hemipterans, primary and accessory (secondary, facultative) endosymbionts are present. More recent studies (for reviews see e.g., BAUMANN \& MORAN 1997; MORAN \& TELANG 1998; BAUMANN 2005) have shown that primary endosymbionts, necessary for growth and development of the host insect, are always present in bacteriocytes and are transovarially (vertically) inherited. In contrast, secondary endosymbionts occur in some populations only, may be vertically as well as horizontally transmitted and may occur intracellularly (i.e., within bacteriocytes or their epithelia) or extracellularly (e.g., free in haemolymph) (FUKATSU et al. 2000; SANDSTRÖM et al. 2001; THAO \& BAUMANN 2004). The symbioses of insects and their primary symbionts are the results of ancient infections, i.e., primary endosymbionts are descendants of bacteria that were acquired by ancestors of insects. In contrast, associations between insects and secondary endosymbionts are much younger and occurred multiple times (MORAN \& TELANG 1998; THAO et al. 2000a; THAO \& BAUMANN 2004; RUSSEL et al. 2003). Since studies concerning the importance of secondary endosymbionts for the host are very few, their role is still unclear. Recently, it has been experimentally proven that pea aphids, Acyrthosiphon pisum, harboring secondary endosymbionts, are more resistant to heat stress (MONTLLOR et al. 2002), parasitic hymenopteran attacks (OLIVER et al. 2003) and fungal pathogens (SCARBOROUGH et al. 2005) than sterile specimens.

In view of the fact that endosymbiosis in a primitive scale insect, Palaeococcus fuscipennis, was not described by BUCHNER (1.c.), this study further elucidates transovarial transmission of microorganisms in this group of insects.

\section{Material and Methods}

Adult females of Palaeococcus fuscipennis (Burmeister) were collected from the stems of Pinus sp. in April 2004 in Adana (Turkey). Ovaries together with accompanying bacteriomes were fixed in $2.5 \%$ glutaraldehyde in $0.1 \mathrm{M}$ phosphate buffer ( $\mathrm{pH}$ 7.4) for 3 months at room temperature. The material was then rinsed in $0.1 \mathrm{M}$ phosphate buffer ( $\mathrm{pH}$ 7.4) with addition of sucrose, postfixed for $1.5 \mathrm{hr}$ in $1 \%$ osmium tetroxide, dehydrated in a series of alcohol and acetone and embedded in epoxy resin Epox 812 (Fullam Inc., Latham, NY, USA). Semithin sections were stained with $1 \%$ methylene blue in $1 \%$ borax and photographed in a Jenalumar (Zeiss Jena) microscope. Ultrathin sections were stained with lead citrate and uranyl acetate and examined using a JEM 100 SX EM electron microscope at $80 \mathrm{kV}$.

\section{Results}

Bacteriomes of Palaeococcus fuscipennis are large, paired organs located in the close vicinity of ovaries (for a detailed description of the ovary of $P$. fuscipennis, see SZKLARZEWICZ et al. 2005). The bacteriomes comprise several large cells termed bacteriocytes (Fig. 1). Each bacteriocyte is surrounded with one-layered epithelium composed of small, flattened cells (Fig. 1). Membranes of both types of cells are equipped with processes that intertwine with each other (Fig. 2). The bacteriocyte cytoplasm is filled with large, pleomorphic bacteria, a ramified nucleus, ribosomes and numerous mitochondria (Fig. 3). The pleomorphic bacteria are surrounded with a cell membrane, the cell wall is not visible (Figs 2,3). The cytoplasm of epithelial cells contains an ovoid nucleus and a small number of coccoid bacteria (Fig. 2). The latter have granular cytoplasm and are surrounded with cell walls (Fig. 2). In the older females containing choriogenic ovarioles both types of microorganisms leave the bacteriocyte cytoplasm (not shown). Released pleomorphic bacteria transform in shape from irregular into spherical. Then, they migrate towards the choriogenic ovarioles and enter the cytoplasm of follicular cells surrounding the posterior pole of the oocyte (Figs 4, 5, 6). After passage through the follicular epithelium, microorganisms locate in the perivitelline space. Egg envelopes are incomplete during the migration of bacteria (Figs 4, 5). The lack of egg coverings around the posterior pole of the oocytes facilitates entry of microorganisms to the perivitelline space (Figs 4, 5). Besides bacteria, the cytoplasm of follicular cells surrounding the posterior pole of the oocyte is filled with numerous cisternae of rough endoplasmic reticulum and vacuoles containing electron-dense granules (Fig. 6). The movement of coccoid bacteria was not observed. During advanced choriogenesis, both pleomorphic as well as coccoid microorganisms are embedded in the flocculent material in the deep depression of the oocyte (Figs 4, 5, 7, 8). In ovaries, as in bacteriocytes, coccoid endosymbionts are less numerous than pleomorphic ones. The pleomorphic bacteria are almost spherical and measure about $5 \mu \mathrm{m}$ in diameter. Like bacteriocytes, the pleomorphic bacteria are surrounded with a cell membrane, the cell wall is not visible (Fig. 8). Within the electrondense cytoplasm, a more translucent nucleoid is visible (Fig. 8). The coccoid bacteria are approximately 1 ěm in length and $0,5 \mu \mathrm{m}$ in breadth. In contrast to pleomorphic microorganisms, they are surrounded with a cell wall (Fig. 7). 

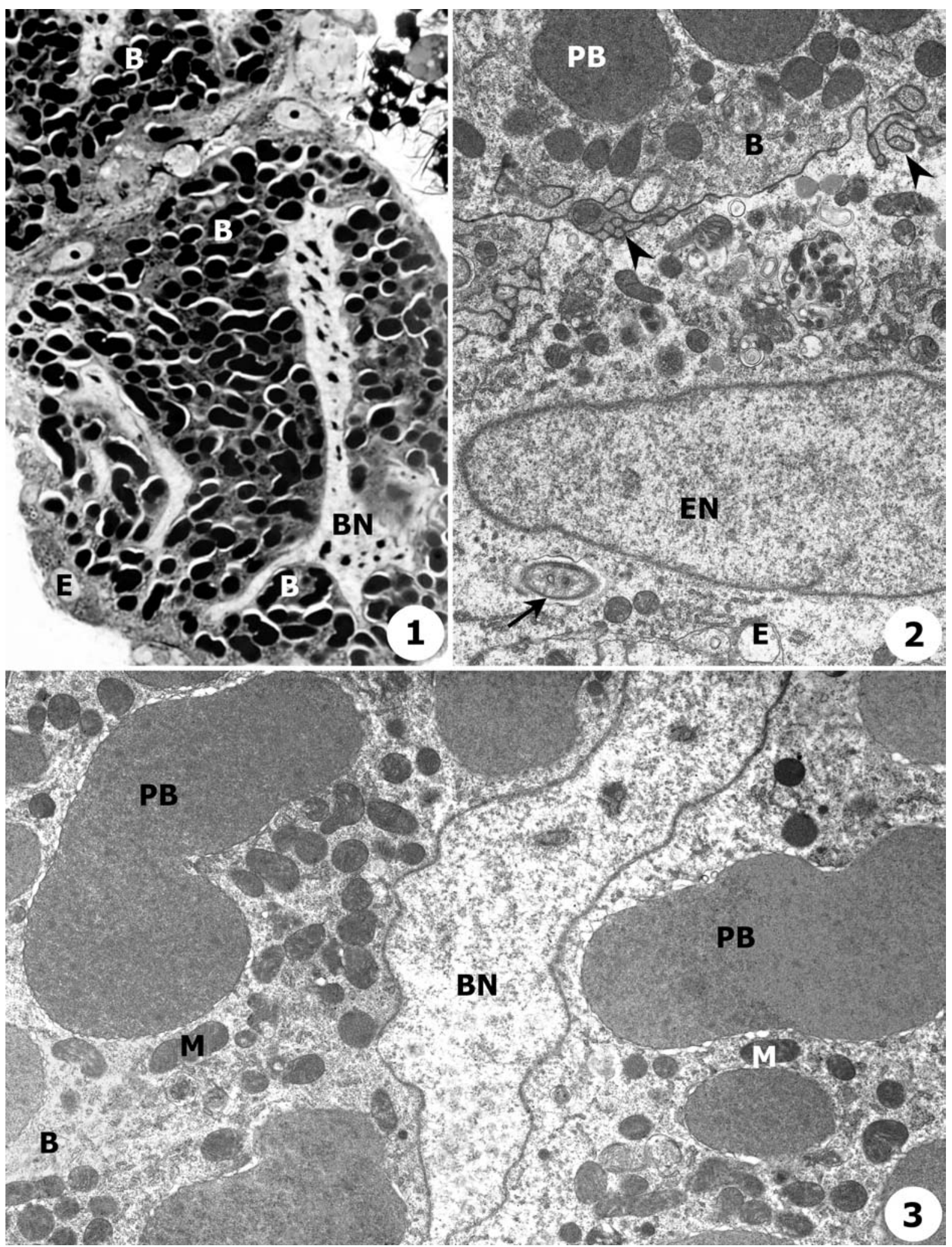

Figs 1-3. Fragment of the bacteriome. B - bacteriocyte, BN - bacteriocyte nucleus, E - epithelial cell, EN - epithelial cell nucleus, $\mathrm{M}$ - mitochondria, PB - pleomorphic bacteria. Fig. 1. Bacteriocytes surrounded by epithelial cells. LM, methylene blue, $\times 1000$. Fig. 2. Fragment of the bacteriocyte and epithelial cell. Arrow - coccoid bacterium, arrowheads - intertwined projections of membranes of the bacteriocyte and epithelial cell. LM, methylene blue, $\times 8$ 400. Fig. 3. Fragment of the bacteriocyte. TEM, $\times 7600$. 


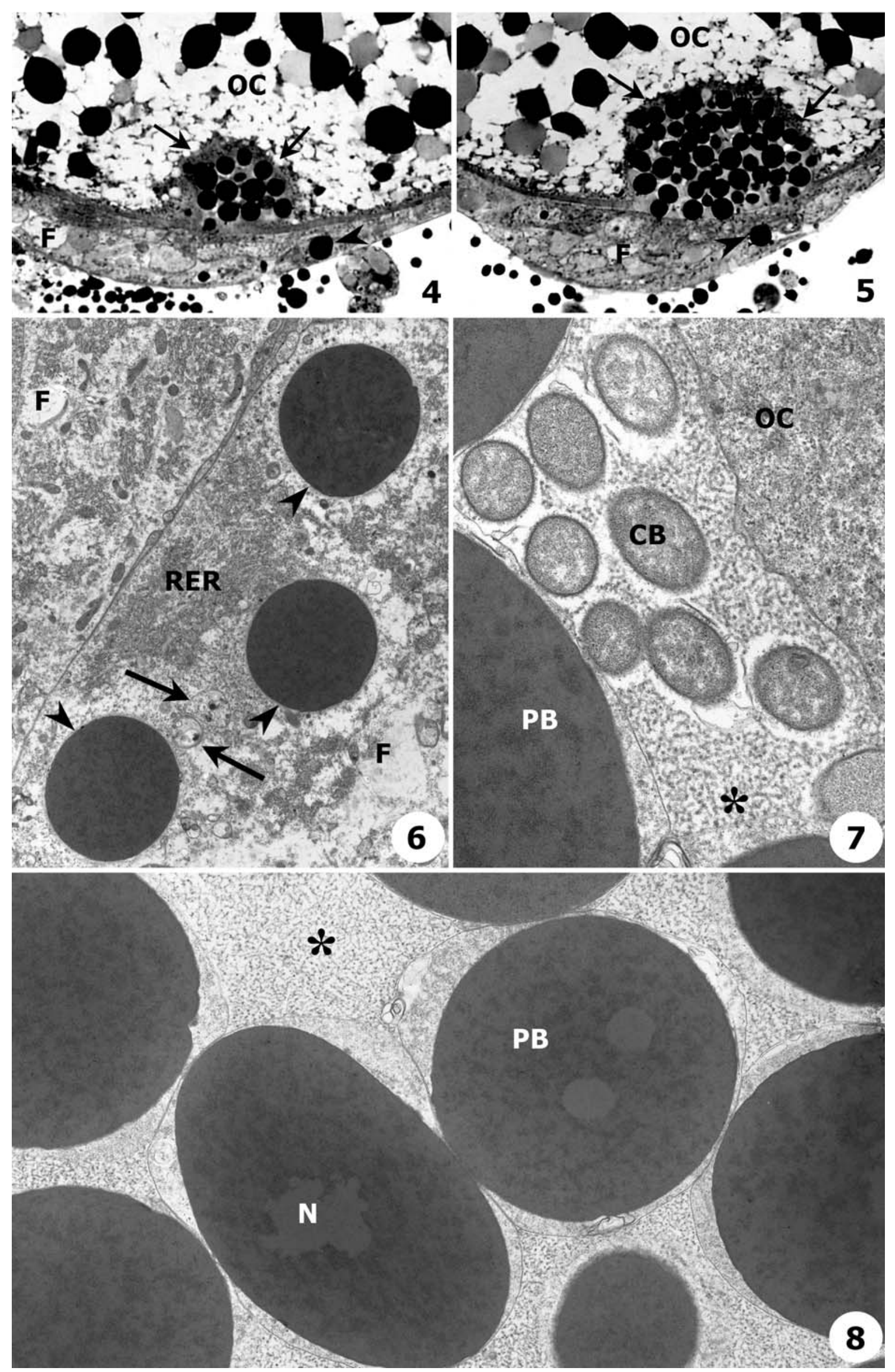


The endosymbionts do not invade the ooplasm until the end of the oocyte growth.

\section{Discussion}

Ultrastructural studies have shown that in the body of Palaeococcus fuscipennis two types of microorganisms, i.e. pleomorphic and coccoid, are present. A similar distribution of endosymbionts has been observed by BUCHNER (1967) in other representatives of the family Monophlebidae, namely Aspidoproctus mirabilis and Walkeriana tosariensis. Thus, our observations support BUCHNER's (1965) conclusion that the family Monophlebidae "...unlike other coccids, is inclined to accept such companion forms". In this light, it may be suggested that the occurrence of two types of endosymbiotic microorganisms is a characteristic feature of the family Monophlebidae.

Since large, pleomorphic bacteria are especially numerous both in bacteriocytes as well as in ovaries, we consider them as the primary endosymbionts of these insects. On the other hand, the small number of coccoid bacteria and their localization in the bacteriocyte epithelium indicate that they are secondary endosymbionts. Besides monophlebids, pleomorphic bacteria have been reported for whiteflies (COSTA et al. 1993; SZKLARZEWICZ \& MOSKAL 2001), cockroaches (MILBURN 1966), psyllids (WAKU \& ENDO 1987; THAO et al. 2000b) and leafhoppers (CHEUNG \& PURCELL 1999). Pleomorphic microorganisms in Palaeococcus as well as in other insects are characterized by a lack of a distinct cell wall. SZKLARZEWICZ \& MOSKAL (2001) postulated that the loss of a cell wall in large, pleomorphic bacteria is connected with their ability for shape modification during migration.

In Palaeococcus, as in other insects, microorganisms start to migrate towards the ovaries simultaneously and all ovarioles containing choriogenic oocytes are infected at the same time. This observation strongly supports the hypothesis that the movement of bacteria is stimulated by an unknown factor released by ovaries (EBERLE \& Mc LEAN 1982; ŻELAZOWSKA \& BILIŃSKI 1999; SZKLARZEWICZ \& MOSKAL 2001). The mode of passage of microorganisms through the follicular epithelium of $P$. fuscipennis is of special interest. In all so far investigated insects, bacteria (or bacteriocytes harboring microorganisms) crawl through the intercellular spaces between neighboring follicular cells (ŻELAZOWSKA \& BILIŃSKI 1999; SZKLARZEWICZ et al. 2000; SZKLARZEWICZ \& MOSKAL 2001), whereas in Palaeococcus pleomorphic endosymbionts enter the cytoplasm of these cells and next undergo exocytosis into the perivitelline space. Contrary to the situation described in other insects, in which younger ovarioles are invaded, microorganisms in Palaeococcus infest ovarioles containing choriogenic oocytes. Since the posterior pole of the oocyte is not covered with egg envelopes, the bacteria can reach the oocyte surface. This situation is very rare among insects and has only been observed in an oviparous generation of an aphid, Stomaphis quercus (PYKA-FOŚCIAK, personal communication). Microorganisms in Stomaphis immediately leave the perivitelline space and invade the oocyte, whereas in Palaeococcus they assemble in the deep depression of the oocyte posterior pole. Ultrastructure of the follicular cells surrounding the posterior pole of the oocyte both in Palaeococus (see Fig. 6) as well as in Stomaphis, indicates that these cells are engaged in the syntheses of precursors of egg envelopes. Thus, it may be postulated that the process of choriogenesis is finally completed once bacteria reach the perivitelline space. The pleomorphic bacteria lying in the perivitelline space are accompanied by coccoid microorganisms. It is probable that due to a small number of the latter, the period of their movement is very short and for this reason has not been observed. The localization of coccoid endosymbionts at the posterior pole of the ovariole suggests that they migrate in the same manner as pleomorphic bacteria. Their function, however, remains unknown.

Since bacteria do not infest the oocyte until the end of oocyte growth, it seems probable that, as in the whitefly Aleurochiton aceris (SZKLARZEWICZ \& MOSKAL 2001), the ooplasm of Palaeococcus is not infested prior to embryonic development.

\section{Acknowledgemens}

We are very grateful to Dr. Beata SZYMAŃSKA and M. Sc. Władysława JANKOWSKA for their skilled technical assistance.

\footnotetext{
Figs 4-8. Posterior pole of the choriogenic ovariole during the migration of endosymbiotic microorganisms. Arrowheads indicate pleomorphic bacteria that transverse the follicular epithelium, short arrows - depression of the oocyte filled with pleomorphic bacteria, long arrows - vacuoles containing electron-dense granules, asterisk - mucous material that fills the depression of the oocyte, CB - coccoid bacteria, F - follicular cells, N- nucleoid, OC - oocyte, PB - pleomorphic bacteria, RER - cisternae of rough endoplasmic reticulum. Figs 4, 5, methylene blue, $\times 700$. Fig. 6 . Pleomorphic bacteria migrate through the cytoplasm of a follicular cell. TEM, $\times 8$ 800. Figs 7, 8. Coccoid and pleomorphic bacteria embedded in the mucous material filling the depression of the oocyte. TEM, Fig. 7, $\times 22$ 100, Fig. 8, $\times 11000$.
} 


\section{References}

BAUMANN P. 2005. Biology of bacteriocyte-associated endosymbionts of plant sup-sucking insects. Annu. Rev. Microbiol. 59: 155-189.

BAUMANN P., MORAN N. A. 1997. Non-cultivable microorganisms from symbiotic associations of insects and other hosts. Antonie van Leeuwenhoek 72: 39-48.

BUCHNER P. 1965. Endosymbiosis of Animals with Plant Microorganisms. Interscience, New York.

BUCHNER P. 1966. Endosymbiosestudien an Schildläusen. VIII. Die Symbiosen der Palaeococcoidea. 1. Teil. Z. Morphol. Ökol. Tiere 56: 275-362.

BUCHNER P. 1967. Endosymbiosestudien an Schildläusen. VIII. Die Symbiosen der Palaeococcoidea. 2. Teil. Z. Morphol. Ökol. Tiere 59: 211-317.

BUCHNER P. 1969. Endosymbiosenstudien an Schildläusen. VIII. Die Symbiosen der Palaeococcoidea. 3. Teil. Z. Morphol. Ökol. Tiere 64: 201-308.

CHEUNG W. W-K., PURCELL A. H. 1999. Invasion of bacteroids and BEV bacterium into oocytes of the leafhopper Euscelidius variegatus Kirschbaum (Homoptera: Cicadellidae): An electron microscopic study. Zool. Stud. 38: 69-75.

Costa H. S., WeStCot D. M., Ullman D. E., Johnson M. W. 1993. Ultrastructure of the endosymbionts of the whitefly, Bemisia tabaci and Trialeurodes vaporariorum. Protoplasma 189: 194-202.

Douglas A. E. 1989. Mycetocyte symbiosis in insects. Biol. Rev. 64: 409-434.

EBERLE M. W., Mc LEAN D. L. 1982. Initiation and orientation of the symbiote migration in the human body louse Pediculus humanus L. J. Insect Physiol. 28: 417-422.

FUKATSU T., NiKOH N., KAWAI R., KOgA R. 2000. The secondary endosymbiotic bacterium of the pea aphid, Acyrthosiphon pisum (Insecta: Homoptera). Appl. Env. Microbiol 66: $2748-2758$

ISHIKAWA H. 1989. Biochemical and molecular aspects of endosymbiosis in insects. Int. Rev. Cytol. 116: 1-45.

KOTEJA J. 1974. On the phylogeny and classification of the scale insects (Homoptera, Coccinea) (discussion based on the morphology of the mouthparts). Acta zool. cracov. 14: 267-325.

Koteja J. 1984. Why the scale insects (Homoptera, Coccinea) are unusual. Phyllogeny and classification of the Margarodidae and related groups (Homoptera: Coccoidea). Proc. Int. Symp. Central Europ. Entomofaunistics 10: 325-327.

KoTEJA J. 1985. Essay on the prehistory of the scale insects (Homoptera, Coccinea). Annal. Zool. 38: 462-503.

Koteja J., PyKA-FoŚCIAK G., VOGELGESANG M., SZKLARZEWICZ T. 2003. Structure of the ovary in Steingelia (Sternorrhyncha: Coccinea), and its phylogenetic implications. Arthr. Struct. Dev. 32: 247-256.
MILBURN N. S. 1966. Fine structure of the pleomorphic bacteroids in the mycetocytes and ovaries of several genera of cocroaches. J. Insect Physiol. 12: 1245-1254.

Montllor C. B., MaXmen A., Purcell A. H. 2002. Facultative bacterial endosymbionts benefit pea aphids Acyrthosiphon pisum under heat stress. Ecol. Entomol. 27: 189-195.

MORAN N. A., BAUMANN P. 2000. Bacterial endosymbionts in animals. Curr. Opin. Microbiol. 3: 270-275.

Moran N. A., TElang A. 1998. Bacteriocyte-associated symbionts of insects: A variety of insect groups harbor ancient prokaryotic endosymbionts. BioScience 48: 295-304.

OLIVER K. M., RUSSEL J. A., MORAN N. A., HUNTER M. S. 2003. Facultative bacterial symbionts in aphids confer resistance to parasitic wasps. Proc. Nat. Acad. Sci. 100: 1803-1807.

Russel J. A., LAtorre A., SABAter-MunOz B., Moya A., MORAN N. A. 2003. Side-stepping secondary symbionts: widespread horizontal transfer across and beyond Aphidoidea. Mol. Ecol. 12: 1061-1075.

SANDSTRÖM J. P., RUSSELL J. A., White J. P., MORAN N. A. 2001. Independent origin and horizontal transfer pf bacterial symbionts of aphids. Mol. Ecol. 10: 217-228.

SCARborough C. L., FerRari J., Godfray H. C. J. 2005. Aphid protected from pathogen by endosymbiont. Science 310: 1781 .

SZKLARZEWICZ T., WNĘK A., BILIŃSKI S.M. 2000. Structure of ovarioles in Adelges laricis, a representative of the primitive aphid family Adelgidae. Acta Zool. Stockholm 81: 307-313.

SZKLARZEWICZ T., MOSKAL A. 2001. Ultrastructure, distribution, and transmission of endosymbionts in the whitefly Aleurochiton aceris Modeer (Insecta, Hemiptera, Aleyrodinea). Protoplasma 218: 45-53.

SZKLARZEWICZ T., KĘDRA K., NiŻNIK S. 2005. Ultrastructural studies of the ovary of Palaeococcus fuscipennis (Burmaister) (Insecta, Hemiptera, Coccinea: Monophlebidae). Folia biol. (Kraków) 53: 45-50

Thao M. L., Clark M. A., Baumann L., Brennan E. B., MORAN N. A., BAUMANN P. 2000a. Secondary endosymbionts of psyllids have been aquired multiple times. Curr. Microbiol. 41: 300-304.

Thao M. L., Moran N. A., AbBot P., Brennan E. B., BURCKHARDT D. H., BAUMANN P. 2000b. Cospeciation of psyllids and their prokaryotic primary endosymbionts. Appl. Env. Microbiol. 66: 2898-2905.

THAO M. L., BAUMANN P. 2004. Evidence for multiple acquisition of Arsenophonus by whitefly species (Sternorrhyncha: Aleyrodidae). Curr. Microbiol. 48: 140-144.

WAKU Y., ENDO Y. 1987. Ultrastructure and life cycle of symbionts in a homopteran insect, Anomoneura mori Schwartz (Psyllidae). Appl. Entomol. Zool. 22: 810-816.

ŻELAZOWSKA M., BILIŃSKI S. M. 1999. Distribution and transmission of endosymbiotic microorganisms in the oocytes of the pig louse, Haematopinus suis (L.) (Insecta: Phthiraptera). Protoplasma 209: 207-213. 